\title{
極浅水域の円柱列周りの3次元流体解析と 波浪実験による精度検証
}

\author{
関口 翔也 1 高木 泰士 2 \\ 1 八千代エンジニヤリング (株) 事業統括本部 国内事業部 港湾・海洋部 \\ （干111-8648 東京都台東区浅草橋 5-20-8 CS タワー） \\ E-mail: sekiguchi.s.ad@gmail.com \\ 2 正会員 東京工業大学大学院准教授 環境・社会理工学院融合理工学系

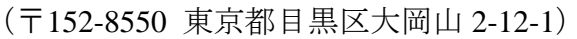 \\ E-mail: takagi@ide.titech.ac.jp
}

\begin{abstract}
開発途上国では木杭が簡便な消波工として使われる.木杭は波打ち際に設置され，波はほぼ完全な砕波 状態で木杭に作用する。このような極浅水域の円筒杭に着目した研究は少なく，消波性能評価や波圧計算 に直ちに使用できる算定式はない。したがって，その設計には極浅水域での波浪変形や流体挙動を精度良 く再現できる解析モデルが必要となる。本研究では，浅瀬を想定した造波水路実験を行い，解析と実験の 結果を比較した. 解析モデルには，波浪解析への応用例も増えつつある OpenFOAM を活用した. 比較の結 果, OpenFOAM による極浅水域の波浪解析は, 砕波点の再現性などに課題が残るものの, 完全に砕波した 後, ボア状の波が到達するような水深条件で特に高い精度を示した．木杭は通常このような場所に設置さ れるため, OpenFOAM は木杭の詳細な検討にも応用できることがわかった。
\end{abstract}

Key Words : developing countries, coastal erosion, wooden piles, cylinder piles, shallow waters, $3 D$ hydrodynamic analysis, OpenFOAM, wave experiment, regular waves

\section{1.はじめに}

筆者らは先の研究で，深刻な海岸侵食により過去 10 年 で最大 $40 \mathrm{~m}$ の海岸線後退が確認されているべトナム・フ アンティエット海岸の状況を調査した ${ }^{1,2), 3), 4)}$. 地方政府 による護岸工事がほとんど行われておらず，侵食により 次々に家屋が流失している海岸があり，そこでは住民が 設置した簡易的な木杭消波工が侵食対策に用いられてい た．木杭は汀線付近の非常に浅い場所に設置される場合 が多く, 年平均レベルの波浪でも完全な砕波状態で木杭 に作用するため，その合理的な設計には，極浅水域での 流体挙動を精度良く再現できる解析モデルが必要になる 1). 杭に関寸る既往研究は, 栈橋や石油プラットフォー ムなど深水深の構造物を対象にした場合が多い。これに 対して，木杭消波工のような極浅水域の円筒杭に数值解 析を適用した事例は少なく，設計など実務的な応用のた めには解析モデルの精度検証が不可欠である.

本研究では，現地の浅瀬を想定した水路床に円柱列を 設置して，造波水路実験を行った．その結果に基づき， 極浅水域における波浪変形や円筒杭を通過する波浪の再 現に3次元流体解析が有効か検証を行った.

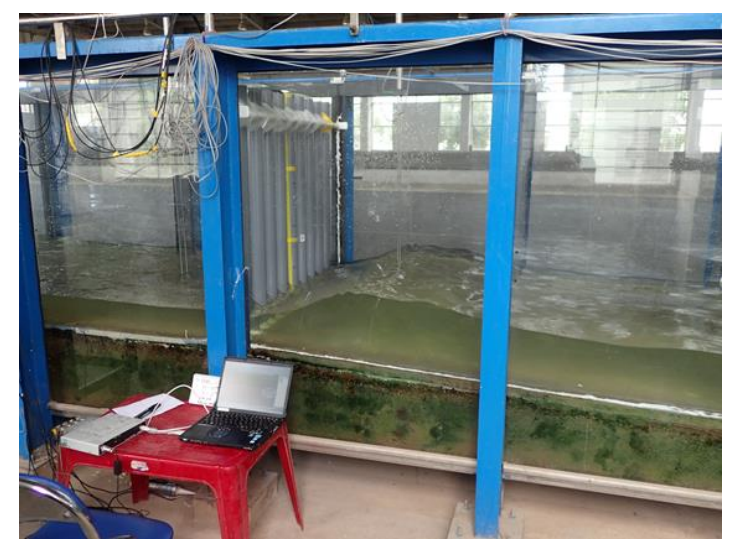

図-1 実験に使用したピストン型造波水路と木杭を模擬し た PVC 杭を設置した造波実験

\section{2. 造波水路実験}

2017年6月にベトナム・ホーチミン市工科大学と共同 で杭模型を設置した造波実験を行った。実験にはベトナ ムの南部水資源研究所(SIWRR)が所有するピストン型造 波水路を使用した（図-1）。水路は全長 $36 \mathrm{~m}$, 幅 $1.2 \mathrm{~m} ゙$ 


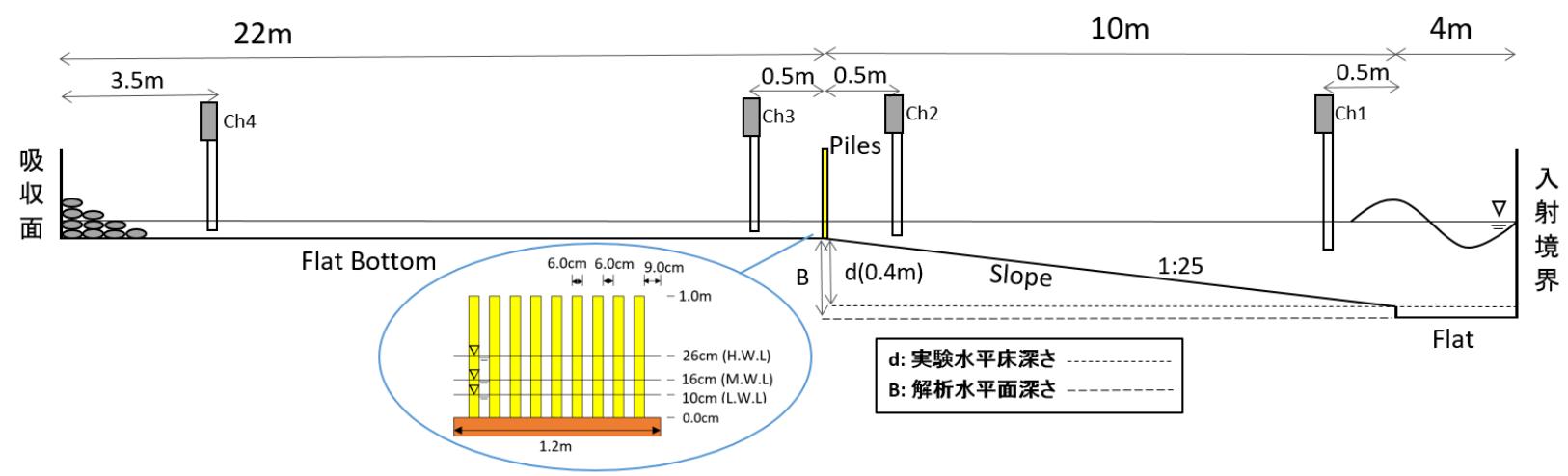

図-2 実験および 3 次元流体解析における地形（岸沖方向）および杭配列（正面図）

あり，図-2に示すように造波板から $14 \mathrm{~m} の$ 地点に，木杭 を模擬した直径 $6 \mathrm{~cm} の \mathrm{PVC}$ プラスチック杭を $6 \mathrm{~cm}$ の隙間 を空けて1列に配置した.波高計測のため4つの水位計(容 量式波高計）を使用し，傾斜の始点から $0.5 \mathrm{~m}$ 地点(Ch1), 杭の前後 $0.5 \mathrm{~m}$ 地点 $(\mathrm{Ch} 2, \mathrm{Ch} 3)$, 水路終点の手前 $3.5 \mathrm{~m}$ （砕 石消波の直前) 地点(Ch4)にそれぞれ設置した．目標とす る入射波条件は波高 $10 \mathrm{~cm} ， 20 \mathrm{~cm}$ ，周期 $2.0 \mathrm{~s}$ の規則波と し，初期水位は杭設置地点において $10 \mathrm{~cm}$ (L.W.L), $16 \mathrm{~cm}$ (M.W.L), $26 \mathrm{~cm}$ (H.W.L)の3条件とした. 通過波を検定寸 るため, 杭を設置していない状態でも同様に実験を行い, 合計12ケースの実験を行った.

\section{OpenFOAM を用いた 3 次元流体解析}

数值解析には, 近年波浪解析一の応用例も増えつつあ る OpenFOAM を活用した. 以下にこのモデルの概要や 検討条件について示寸.

\section{(1) 解析モデル・条件}

本数值解析で用いた解析ソフト OpenFOAMには interFoamというソルバが標準で導入されており, VOF法 を用いた非圧縮2相流ソルバである. 基礎方程式を以下に 示す.

$$
\begin{gathered}
\frac{\partial \rho}{\partial \mathrm{t}}+\nabla(\rho u)=0 \\
\frac{\partial(\rho u)}{\partial \mathrm{t}}+\nabla(\rho u u)=-\nabla(p)+\mu \nabla(\nabla u)+\rho g \\
\rho=\alpha \rho_{1}+(1-\alpha) \rho_{2}
\end{gathered}
$$

ここで, $u$ : 流速ベクトル, $p$ : 圧力, $\mu$ : 流体の粘性係 数, $g$ : 重力加速度ベクトルであり, $\rho_{1}, \rho_{2}$ は水之空気の 密度, $\alpha$ は水の体積分率 $(0<\alpha<1)$ である. 本数值解析では 造波境界での反射波吸収機能を用いるため, interFoamを
表-1 各ケースにおける目標波高 $\mathrm{H}_{\mathrm{t}}$, 造波境界入力波高 $\mathrm{H}_{\mathrm{I}}$ および周期 $\mathrm{T}$ と水平面の深度 $\mathrm{B}$ (解析)， $\mathrm{d}$ (実 験) (図-2参照)

\begin{tabular}{|c|c|c|c|c|}
\hline ケース & $\mathrm{H}_{\mathrm{I}}(\mathrm{cm})$ & $\mathrm{T}(\mathrm{s})$ & $\mathrm{B}(\mathrm{m})$ & $\mathrm{d}(\mathrm{m})$ \\
\hline H.W.L $・ H t=10 \mathrm{~cm}$ & 10.7 & 2.0 & 0.4 & 0.4 \\
\hline H.W.L $\cdot \mathrm{Ht}=20 \mathrm{~cm}$ & 20.1 & 2.0 & 0.55 & 0.4 \\
\hline M.W.L $\cdot \mathrm{Ht}=10 \mathrm{~cm}$ & 9.8 & 2.0 & 0.4 & 0.4 \\
\hline M.W.L $\cdot \mathrm{Ht}=20 \mathrm{~cm}$ & 19.1 & 2.0 & 0.47 & 0.4 \\
\hline L.W.L $\cdot \mathrm{Ht}=10 \mathrm{~cm}$ & 10.0 & 2.0 & 0.45 & 0.4 \\
\hline L.W.L $\cdot \mathrm{Ht}=20 \mathrm{~cm}$ & 20.0 & 2.0 & 0.45 & 0.4 \\
\hline
\end{tabular}

もとに, IHcantabria ${ }^{5}$ が波浪場解析に拡張したIHFoamソ ルバを使用した。乱流モデルには杭周囲での複雑な流体 現象を評価するためLES-Smagorinsky SGSモデルを設定 した. 本モデルを東京工業大学所有のスーパーコンピュ ータTSUBAME3.0（汎用CPUと GPU型アクセラレータに より単精度24.3 PFLOPS）に移植し，並列解析により解 析時間の大幅短縮を図った. 並列数112で, 時間ステップ

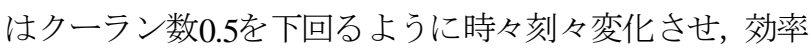
化を図ったが，計算格子数が約729万に達したため， 55 秒間の解析でも実計算時間で約4時間を要した.

図-2に示寸よう解析での地形は実験床の傾斜の始点 （造波板から $4 \mathrm{~m}$ 地点）から水路終点（造波板から $36 \mathrm{~m}$ 地点）まで実験と同一の条件となるようCADを用いて正 確に作成した，但し，実験では水路の終端に吸収帯とな る砕石を設置したが，解析では代わりに反射波吸収境界 を設定した．また，実験でのピストン式造波の代替とし て解析では固定境界より正弦波を入射させた，実験と解 析で同一の入射波と寸るため波高計Ch1（傾斜開始より $50 \mathrm{~cm}$ 地点) で両者がほぼ同じ波となるよう入射境界上の 入力波 $\mathrm{H}_{\mathrm{I}}$ と水平床の深度B (図-2) を試行錯誤の上調節 し，表-1の入射波条件を得た。計算格子サイズは計算量 の削減のため地形モデル全体を最大 $24 \mathrm{~cm}$ と粗く設定し, 詳細な再現が必要な杭周辺や水面，水中，底面付近の格 子サイズを細かく設定した．特に杭周辺の計算格子を細 かく設定し, 最も精緻な箇所で $1.5 \mathrm{~cm}$ に設定した (図-3). 


\section{（2）実験と解析の波高比較（杭無し条件）}

図-4にH.W.L，目標波高（以下， $\left.\mathrm{H}_{t}\right) 10 \mathrm{~cm}$ 杭無し久 一スでの C1 1の波高比較を示す. Ch1地点では确波は発生

しておらず，実験と解析は非常によく一致している．な

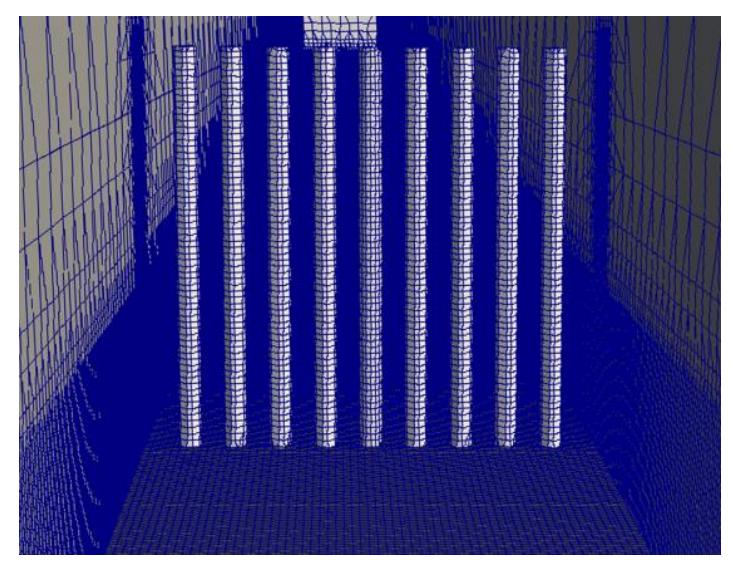

図-3 杭周辺の計算格子（入射境界側から見た図）
お，一部の実験ケースで微小な（1 cm以下）水面のゆら ぎが発生しているケースが見られた。これは実験前に 30 分ほどの静水待ちを行ったが，ごくわずかな長周期の波 が残っていたためと考えられる.

杭設置位置近傍での解析精度を検証するため, 杭前後 $50 \mathrm{~cm}$ に配置したCh2，Ch3で測定した水位変化からゼロ アップクロス法で 1 波を定義し，実験と解析の波高を 個々の波ごとに比較した．ここで，造波開始後の立ち上 がり部分のデータを取り除き，造波板からの再反射の影 響を受けていない波を抽出した. 抽出された波の数は, ケースにより異なり最小で 14 波, 最大で 21 波であった. さらに, $t$ 分布表から各ケースのサンプル数の $5 \%$ 基隻值 （両側検定）を読み取り，実験值の平均值および95\%信 頼区間を算出した. 図-5および図-6に杭無しケースでの Ch2，Ch3の波形を示し，表-2に観測された平均波高およ び実験值の $95 \%$ 信頼区間に収まった解析值の波数を示 す. 但し, Ch3ではH.W.L・ $\mathrm{H}_{\mathrm{t}}=20 \mathrm{~cm}$ 実験データに欠 落があったため除外した．また，図-7に杭無しケースの

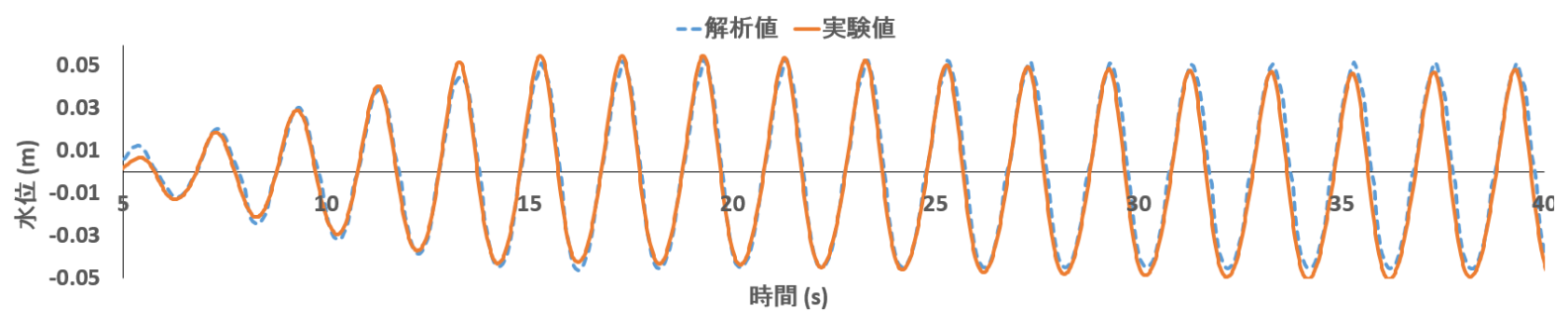

図-4 Ch1（造波板前面約 $4.5 \mathrm{~m} ）$ の水位比較 $\left(\mathrm{H} . \mathrm{W} . \mathrm{L} \cdot \mathrm{H}_{\mathrm{t}}=10 \mathrm{~cm}\right.$, 杭無し)

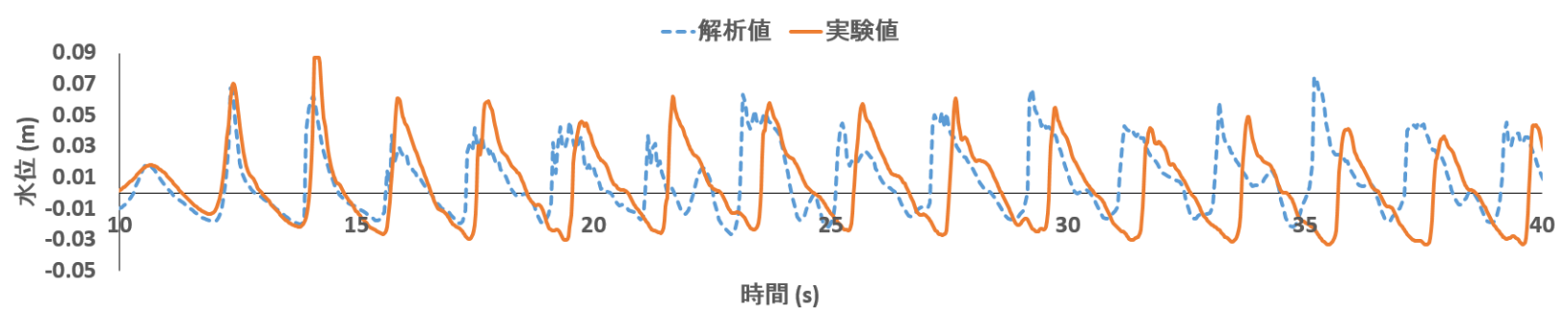

図-5 Ch2（杭前面沖側 $50 \mathrm{~cm} ）$ の水位比較 $\left(\mathrm{L} . \mathrm{W} . \mathrm{L} \cdot \mathrm{H}_{\mathrm{t}}=20 \mathrm{~cm}\right.$, 杭無し)

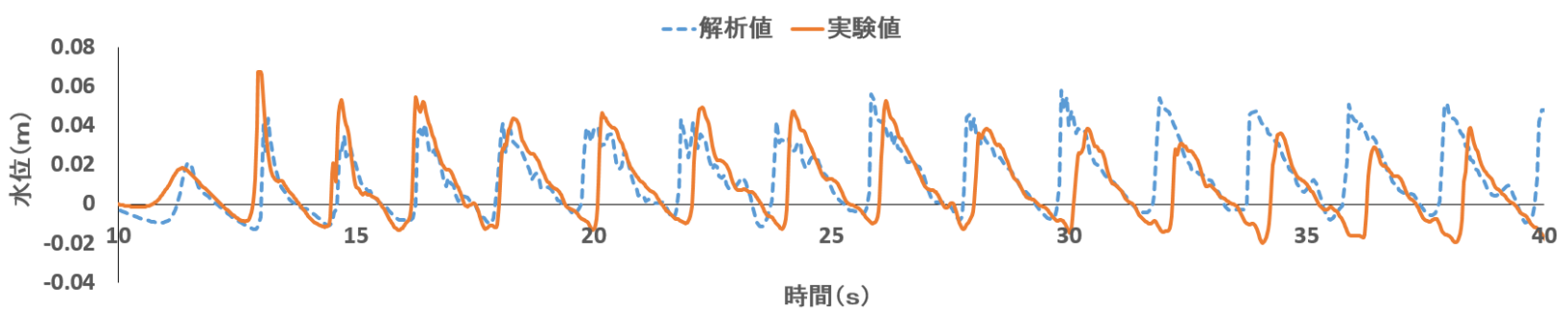

図-6 Ch3（杭背面岸側 $50 \mathrm{~cm}$ ） の水位比較 (L.W.L $\cdot \mathrm{H}_{\mathrm{t}}=20 \mathrm{~cm}$, 杭無し) 
表-2 各ケースの杭前後（Ch2, Ch3）で観測された平均波高および実験值の95\%信頼区閒内に収まった解析上の波数（但し， H.W.L・Ht $=20 \mathrm{~cm}$ 実験データ不良のため除外)

\begin{tabular}{|c|c|c|c|c|c|}
\hline 杭無L (Ch2) & 観測波数 & 解析平均波高 $(\mathrm{m})$ & 寒験平均波高 $(\mathrm{m})$ & 波高差(解析 - 赛験) & 信頼区間に收まった波数 \\
\hline H.W.L $+\mathrm{Ht}=10 \mathrm{~cm}$ & 14 & 0.1159 & 0.1134 & $0.0026(2.3 \%)$ & $12(86 \%)$ \\
\hline H.W.L $+\mathrm{Ht}=20 \mathrm{~cm}$ & 16 & 0.2084 & 0.2388 & $-0.0304(-13 \%)$ & $7(44 \%)$ \\
\hline M.W.L $+\mathrm{Ht}=10 \mathrm{~cm}$ & 17 & 0.1315 & 0.1303 & $0.0012(0.9 \%)$ & $17(100 \%)$ \\
\hline M.W.L $+\mathrm{Ht}=20 \mathrm{~cm}$ & 21 & 0.0829 & 0.1030 & $-0.0201(-20 \%)$ & $16(76 \%)$ \\
\hline L.W.L $+\mathrm{Ht}=10 \mathrm{~cm}$ & 16 & 0.0684 & 0.1228 & $-0.0543(-44 \%)$ & $0(0 \%)$ \\
\hline L.W.L $+\mathrm{Ht}=20 \mathrm{~cm}$ & 17 & 0.0699 & 0.0762 & $-0.0063(-8.3 \%)$ & $14(82 \%)$ \\
\hline 杭無し (Ch3) & 観測波数 & 解析平均波高 $(\mathrm{m})$ & 実験平均波高 $(\mathrm{m})$ & 波高差(解析 - 実験) & 信頼区間に收害った波数 \\
\hline H.W.L $+\mathrm{Ht}=10 \mathrm{~cm}$ & 14 & 0.1256 & 0.1249 & $0.0007(0.5 \%)$ & $14(100 \%)$ \\
\hline H.W.L $+\mathrm{Ht}=20 \mathrm{~cm}$ & - & - & - & - & - \\
\hline M.W.L $\cdot \mathrm{Ht}=10 \mathrm{~cm}$ & 17 & 0.1053 & 0.1300 & $-0.0246(-19 \%)$ & $0(0 \%)$ \\
\hline M.W.L $+\mathrm{Ht}=20 \mathrm{~cm}$ & 21 & 0.0653 & 0.0771 & $-0.0117(-15 \%)$ & $12(57 \%)$ \\
\hline L.W.L $+\mathrm{Ht}=10 \mathrm{~cm}$ & 16 & 0.0338 & 0.0575 & $-0.0237(-41 \%)$ & $1(6 \%)$ \\
\hline $\mathrm{L} . \mathrm{W} . \mathrm{L}+\mathrm{Ht}=20 \mathrm{~cm}$ & 17 & 0.0545 & 0.0531 & \begin{tabular}{|l|}
$0.0014(2.7 \%)$ \\
\end{tabular} & $17(100 \%)$ \\
\hline 梳有り(Ch3) & 観測波数 & 解析平均波高 $(\mathrm{m})$ & 実験平均波高 $(\mathrm{m})$ & 波高差(解析 - 実験) & 信頼区間に叹まった波数 \\
\hline H.W.L $+\mathrm{Ht}=10 \mathrm{~cm}$ & 15 & 0.1136 & 0.1250 & $-0.0114(9.1 \%)$ & $0(0 \%)$ \\
\hline L.W.L $+\mathrm{Ht}=20 \mathrm{~cm}$ & 15 & 0.0541 & 0.0537 & $0.0004(0.6 \%)$ & $15(100 \%)$ \\
\hline
\end{tabular}

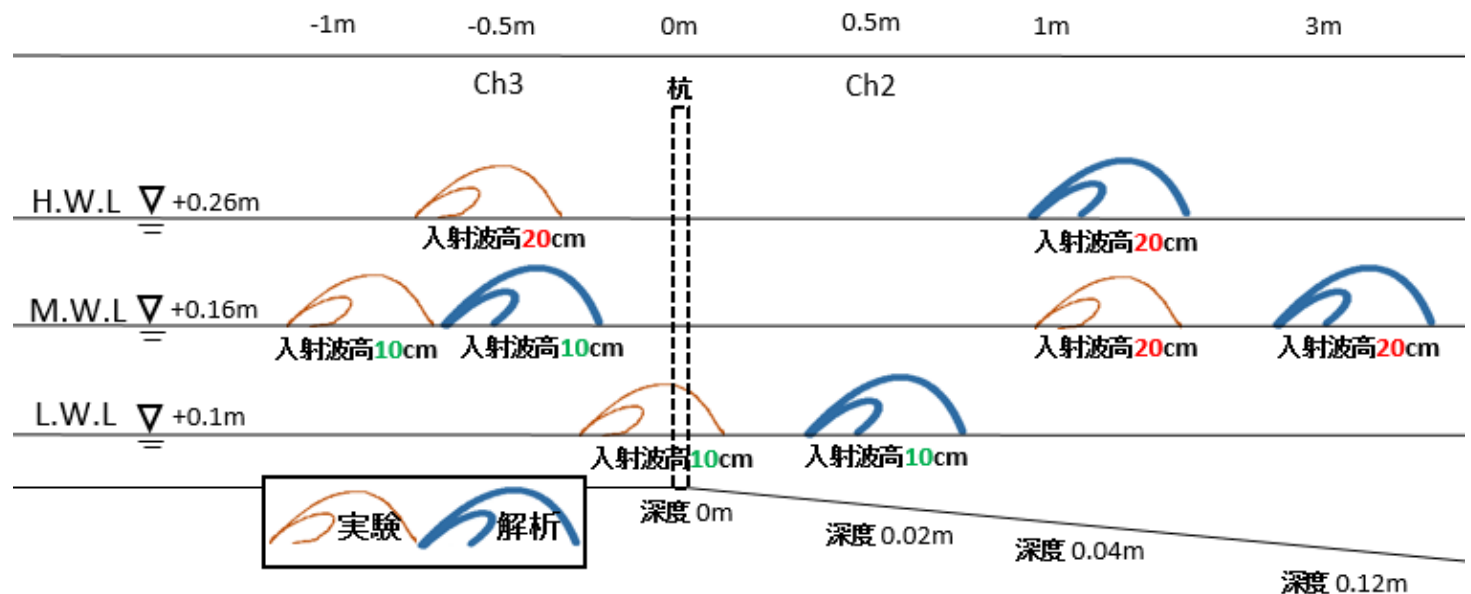

図-7＼cjkstart杭無しケースにおける実験・解析の各砕波点（判別範囲 : 杭近傍 $-1 \mathrm{~m} \sim 3 \mathrm{~m}$ )

実験および解析のおおよその砕波点を示す。動画より目 視で判断したため数十センチ程度の誤差がありえる.

L.W.L・ $\mathrm{H}_{\mathrm{t}}=20 \mathrm{~cm}$ ケケースは図領域外の斜面途中で砕波 しており, H.W.L・ $\mathrm{H}_{\mathrm{t}}=10 \mathrm{~cm}$ ケースは領域を通過後に 砕波し, 動画に収まっていなかったため記載していない.

H.W.L・ $\mathrm{H}_{\mathrm{t}}=10 \mathrm{~cm}, \quad$ L.W.L・ $\mathrm{H}_{\mathrm{t}}=20 \mathrm{~cm}$ の 2ケースは, Ch2, Ch3 共に解析值が実験值の $95 \%$ 信頼区間内におおむ ね収まっており，良好な再現性が確認できる（表-2）。こ の2ケースは砕波地点がC2およびC3から離れているケ 一スであり，これらの波高計の場所で非砕波あるいは完 全砕波の状態で波が伝播している. 関口・高木 ${ }^{1}$ が実施し た解析では，現地においても完全砕波の状態で波が木杭 に作用することを確認しているが，本解析では L.W.L・ $\mathrm{H}_{\mathrm{t}}=20 \mathrm{~cm}$ のケースがこの条件に一番近い.

その他の解析4ケースでは，杭無し条件での比較で, 波高が最大 $44 \%$ 程度過小評価されている。これらのケー
スでは実験と解析の間で，砕波点にわずかな違いが生じ ており(図-7)，砕波の発生有無の違いが波高の差として 顕著に現れたと考えられる。 また，砕波が $\mathrm{h} 3$ 近傍で発 生しているM.W.L・ $\mathrm{H}_{\mathrm{t}}=10 \mathrm{~cm}$ ケースは, Ch2での解析 值と実験值が良好に一致しているが，C3に関しては， 多くの解析值が実験值の95\%信頼区間に収まっていな い(表-2).このように, 砕波地点が観測点に近いと解析 精度が低下する傾向がある. また，これら4ケースすべて で解析值が実験值に比べて過小となっており，解析では 実験と比べて砕波しやすく，砕波点が入射境界側に寄つ ていることがわかる。

\section{（3）実験と解析の波高比較（杭有り条件）}

前節の杭無し条件で特に再現性が高いことが確認さ れた2条件（H.W.L・ $\mathrm{H}_{\mathrm{t}}=10 \mathrm{~cm}$, L.W.L $\left.\cdot \mathrm{H}_{\mathrm{t}}=20 \mathrm{~cm}\right)$ に 関して, 杭有り条件でも解析を行い, 実験值と解析值を 
比較した. 図-8に杭背後（Ch3）の波高比較を示す. 杭 有りL.W.L・ $\mathrm{H}_{\mathrm{t}}=20 \mathrm{~cm}$ ケケースではすべての解析值が実 験值の95\%信頼区間に収まっており（表-2），杭を通過す る波浪に対しても高い解析精度であることがわかる。こ れに対して, H.W.L・H $\mathrm{H}_{\mathrm{t}}=10 \mathrm{~cm}$ のケースは $95 \%$ 信頼区 間には収まっていない. しかし, 図-8に示すように解析 值と実験值の誤差は20\%程度で，かつ誤差が一対一の軸 回りにばらついており，解析の信頼性は比較的高いとい える.

通常木杭消波工は人力で波打ち際の極浅水深に設置 され1)，常時波浪のレベルでも，ほぼ完全に砕波した状 態で波浪が作用する。したがって，LW.Lの水位条件に 対する推定精度が特に高い本解析モデルは木杭消波工の 設計に有用と考えられる.

なお， LW.L・ $\mathrm{H}_{\mathrm{t}}=20 \mathrm{~cm}$ ケケースではCh2およびCh3 の解析が実験と比べて $1 \mathrm{~cm}$ 程度上昇した（図-5, 図-6, 図-9).この要因としては, 解析において反射波吸収境界 で波が完全に吸収されなかったことや，浅水変形が過大 評価されたこと, 杭周囲で水塊の滞留が発生したことな どが考えられるが原因の特定はできていない.

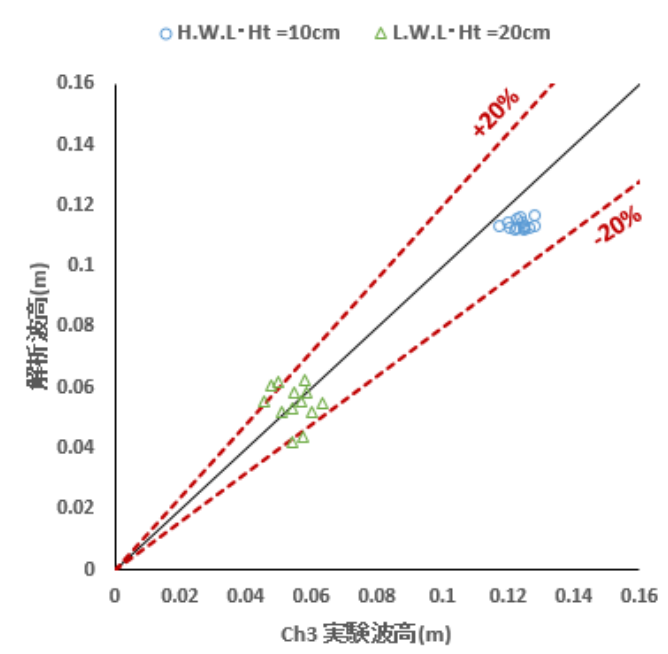

図-8 Ch3（杭背面岸側 50cm） での波高比較（杭有り）

\section{（4）通過波に対する杭の効果}

L.W.L・ $\mathrm{H}_{\mathrm{t}}=20 \mathrm{~cm}$ の杭背後Ch3の平均波高は, 実験・ 解析ともに杭の有無に伴う波高変化は $1 \mathrm{~mm}$ 以下である

(表-2).したがって, 今回の配置パターンでは透過率が 100\%に近く, 杭の波高減衰効果はほとんどないといえる.

図-10に杭周辺の断面流速ベクトルを杭有り・無しで比 較した一例を示す。上段が波浪到達前（29.3秒），下段が 杭位置通過中（29.9秒）のスナップショットであり, 各々 上図が杭有り，下図が杭無しのケースである．波浪到達 前は杭有り無しに関わらず，流速べクトルがおおむね水 平方向である. これに対して, 波浪通過中では杭有りの ケースで顕著な鉛直流速成分が現れて，杭背後では強い 蛇行現象が見られる. これは杭の前面と背面での水位差 に伴い，鉛直下向きの流速ベクトルが発生するためと考 えられる。このような現象は木杭無しのケースでは発生 しておらず，杭の設置が波の流速ベクトルに影響を及ぼ

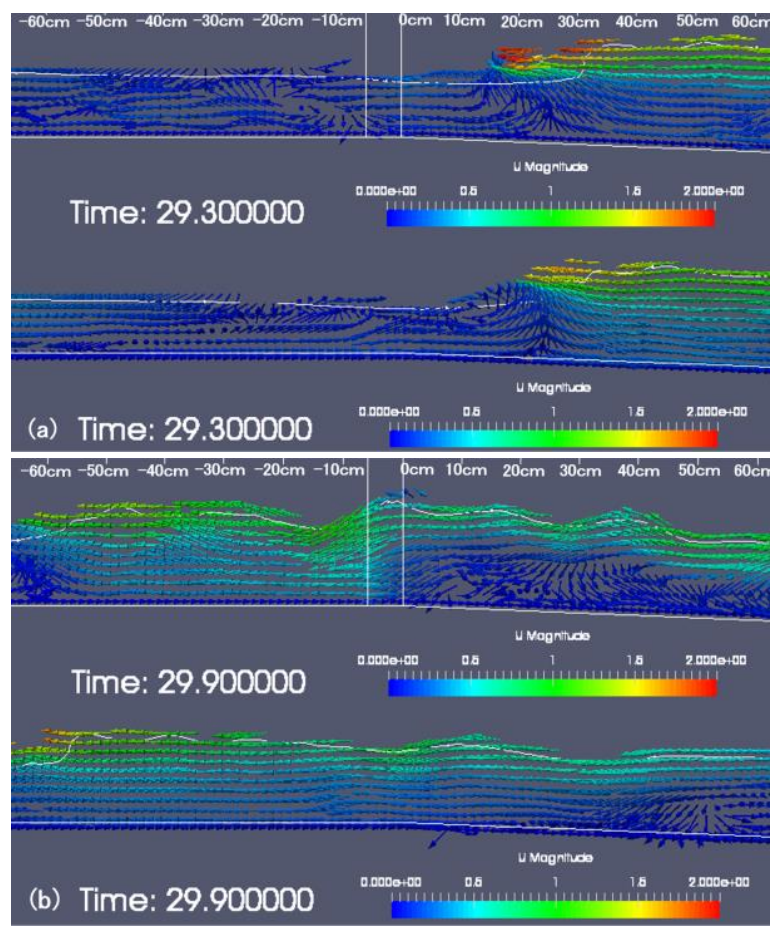

図-10 L.W.L・ $\mathrm{H}_{\mathrm{t}}=20 \mathrm{~cm}$ での流速ベクトルの変化 (a) 29.3 秒, (b) 29.9 秒（上部 : 杭有り, 下部 : 杭無し) (右方 向より波浪が伝播)

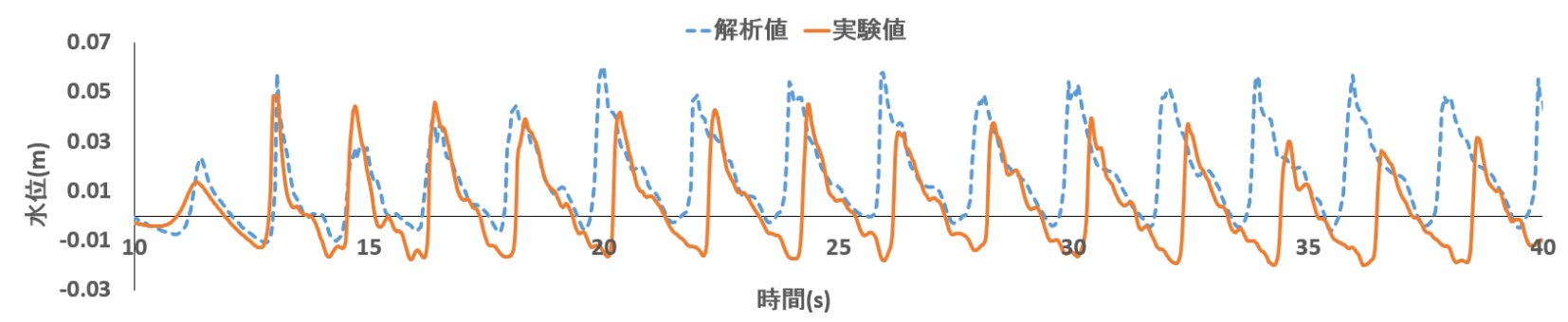

図-9 Ch3（杭背面岸側 50cm） の水位比較 $\left(\right.$ L.W.L $\cdot \mathrm{H}_{\mathrm{t}}=20 \mathrm{~cm}$, 杭有り） 
したと考えられる.

筆者らの先の研究 ${ }^{1)}$ では, ベトナム・ファンティエッ ト海岸のケーススタディで木杭消波工によって波浪の遡 上が若干軽減することを示したが，この蛇行現象がその 一因になっている可能性がある。したがって，通過波に 対する杭の効果を検討する際には，波高は減衰しない場 合でも，流速や流向の変化を通じて効果を発揮する可能 性があるため，今後の研究では留意する必要がある.

\section{4. 結論}

本研究では，浅瀬を想定した水路床に円柱列を設置し て，造波水路実験を行い，OpenFOAMによる解析と実験 の結果を比較した．OpenFOAMによる波浪解析は，完全 に砕波した後, ボア状の波が到達寸るような極浅水域で, 解析值が実験值の $95 \%$ 信頼区間に収まり，十分な解析精 度を示すことがわかった，通常木杭消波工は，このよう な波打ち際の極浅水域に設置されるため, OpenFOAMに よる3次元流体解析は木杭消波工の設計にも有用といえ る。その一方で，砕波の発生が実験よりも早めに現れる 傾向や，杭周囲での過大な水位上昇，砕波点付近での波 高の過小評価など課題も残っている. また，杭の効果を 検討する際には，杭前後の波高変化だけでなく，流速・
流向変化にも留意する必要があることを示した。

謝辞 : 住友財団環境研究助成(No.163017)および科学研究 費助成事業国際共同研究加速基金(16KK0121)の支援の 下実施した.また, 実験は Nguyen Danh Thao 博士, Nguyen Kiet 氏の協力を得た。 ここに記して謝意を表する.

\section{参考文献}

1）関口翔也，高木泰士，不規則波を考慮した 3 次元流体 解析の木杭消波工設計への応用，土木学会論文集 B3 (海洋開発), Vol. 73, No. 2, pp. 48-53, 2017.

2) 高木泰士, Nguyen Danh Thao, Miguel Esteban, Tran Thu Tam, Hanne Louise Knaepen, 三上貴仁: ベトナム南部 の沿岸域における災害脆弱性の検証，土木学会論文 集 B3（海洋開発）, Vol. 68, No. 4, pp.888-893, 2012.

3) Takagi H., Esteban M., Tam T. T.: Coastal Vulnerabilities in a Fast-Growing Vietnamese City, Coastal Disasters and Climate Change in Vietnam, Elsevier, pp.157-171, 2014.

4) 高木泰士, グェン ダン タオ，レ バン コング : 高い 経済成長の渦中にあるべトナムの沿岸域開発の現状, 沿岸域学会誌, Vol.21, No.4, pp.113-122, 2008.

5) Higuera P., Lara J. L., Losada I. J.: Three-dimensional interaction of waves and porous coastal structures using OpenFOAM to breaking of random waves, Coastal Engineering, 83, pp. 57-72, 2014.

\title{
THREE-DIMENSIONAL HYDRODYNAMIC ANALYSIS AROUND CYLINDRI- CAL ROWS IN SHALLOW WATERS AND VERIFICARION OF ACCUEACY BY WAVE EXPERIMENTS
}

\author{
Shoya SEKIGUCHI and Hiroshi TAKAGI
}

In developing countries, wood piles are often used as a simple breakwater solution. In the previous study, the authors investigated the situation on the Phan Thiet coast in Vietnam, where wood piles were installed by local people to stop severe coastal erosion. On this beach the waves are mainly reaching the installed wood piles in a completely broken state. In order to create scientifically proven design for wood piles defense, an analytical model, which accurately reproduces fluid behavior in shallow waters, is needed. However, few studies focus on cylindrical piles in shallow waters, but it is essential to verify the accuracy of those analytical models with the aim of future sound implementation by local communities. In this study, a wave-flume experiment was conducted with the cylindrical piles installed at a shallow-depth floor, assuming simplified beach profile. OpenFOAM, which draws attention as a tool of wave analysis in recent years, was applied in this study. The results of analysis and experiment we re compared to investigate the reliability of the model. It was found that the wave analys is by OpenFOAM shows sufficient accuracy particularly in very shallow-depth conditions in which most of waves are forced to break, and consequently bore-like waves impact the piles. 